\title{
An empirical approach for reliable microsatellite genotyping of wolf DNA from multiple noninvasive sources
}

\author{
Massimo Scandura $\cdot$ Claudia Capitani $\cdot$ \\ Laura Iacolina $\cdot$ Marco Apollonio
}

Published online: 19 October 2006

(C) Springer Science+Business Media B.V. 2006

\section{Erratum to: Conservation Genetics \\ DOI 10.1007/s10592-005-9106-5}

The last author's name was inverted in the original article, it is Marco Apollonio and not Apollonio Marco.

The online version of the original article can be found at http:// www.dx.doi.org/10.1007/s10592-005-9106-5

M. Scandura · C. Capitani - L. Iacolina · M. Apollonio Department of Zoology and Anthropology,

University of Sassari, Via Muroni 25,

I-07100 Sassari, Italy

M. Scandura ( $\square)$

Lehrstuhl für Verhaltensforschung,

Universität Bielefeld, Morgenbreede 45,

D-33615 Bielefeld

Germany

e-mail: scandura@uniss.it 